\title{
Preacutionary labelling of cross-reactive foods: The case of rapeseed
}

\author{
Alessandro Fiocchi ${ }^{*} \mathbb{D}$, Lamia Dahdah, Carla Riccardi, Oscar Mazzina and Vincenzo Fierro
}

\begin{abstract}
Food allergic individuals are exposed to unnecessary dietary restrictions due to precautionary food allergy labelling (PFAL). Two forms of PFAL exist: type I identifies the possible presence of allergenic contaminaion in foods ('may content...'), type II indicates as potentially dangerous ingredients or contaminants that do no belong to official list of food allergens. PFAL type II is based on the fear of cross-reactivity with foods belonging to that list. PFAL type II is less known, but may be tempting for the legal offices of food companies, for clinicians in a 'defensive medicine' key, and even for legislators. We identify here a case of PFAL type II, allergy to rapeseed (belonging to the family of Brassicaceae). Increasingly used for their nutritional and nutraceutic value in asthma prevention, rapeseed has been indicated by regulatory authorities in Canada and Europe as potential cross-reactor with mustard. In this review, we provide the elements for a risk assessment of cross-reactivity of rapeseed/mustard allergy in the general population both clinically and from the point of view of the molecular allergy. Three findings emerge:

1. Allergic reactions to rapeseed are exceptional

2. The allergens identified in rapeseed and mustard are similar, but not identical

3. Reactions to rapeseed have never been described in mustard-allergic patients.

On the ground of existing evidence, a precautionary labeling for rapeseed as potentially dangerous for patients

allergic to mustard is not justified. In the interest of patients with multiple food allergy, PFAL type II must be avoided.
\end{abstract}

\section{Background}

Labelling is an issue of relevance to food allergic consumers of fresh, processed or pre-packaged foods, as accidental ingestion of food allergens due to labelling ambiguities is a modifiable risk factor. In the European Union, twelve food items are required by law to appear on the label of pre-packaged foods: cereals containing gluten, crustaceans, egg, fish, peanut, soy, milk (including lactose), nuts, mustard, sesame seeds, celery, and sulphites $>10 \mathrm{mg} / \mathrm{kg}$ [1]. Similar legislation is in effect in the US for only eight foods: milk, egg, peanut, tree nuts, shellfish, fish, soy and wheat [2]. This list do not include mustard, present in the Canada list [3]. The legislation minimizes the risk that unfamiliar names can hide allergenic foods, as for instance "starch" is replaced by "corn starch" or "wheat starch"; "Lysozyme" by "lysozyme, containing egg", and so on.

\footnotetext{
* Correspondence: agiovanni.fiocchi@opbg.net

Ospedale Pediatrico Bambino Gesù, Dipartimento Pediatrico Universitario

Ospedaliero (DPUO), UOC Allergologia, Rome, Vatican City, Italy
}

On both the sides of Atlantic, the regulatory problem is now the opposite: whether too many foods containing allergenic foods are being labeled as allergenic, and whether this would potentially restrict potentially safe food choices for allergic consumers [4].

Precautionary Food Allergy Labelling (PFAL) has two faces.

The first is the labelling of existent, or not completely excludible, trace amounts of the allergenic foods: no legislation prescribes the indication of potential contaminants, but many manufacturers are now warning of potential contaminations during food preparation. The ways to express such kind of PFAL are so many, that the regulatory authorities in some countries felt the need to regulate this aspect also [5]. This is the case of Canada, where from 2012 the only permitted expression is "may contain $[\mathrm{X}]$ " [6]. We will call this PFAL type I.

The labelling of potentially cross-reacting foods (PFAL type II) is another example of potential overlabelling. Leguminosae are exempt from this risk in Europe and the Sates, as the indication is very specific for peanut 
and for soy, so that lentil, pea or bean will not be labeled as 'potentially cross-reactive'. For milk, the European legislation is clear in indicating that it should be labelled irrespective of its animal origin, reflecting the likely cross-reactivity between cow, sheep, goat, buffalo etc. However, the requirement of labelling lactose as allergenic contradicts the fact that this sugar has never been reported to determine allergic reactions after ingestion among children with CMA [7].

For mustard, it seems clear both in EU and in Canada that this should be the only member of the Brassicaceae family to be labeled. Yet, in the explanatory documents, Health Canada warns consumers with mustard allergy to avoid consuming other members of the Brassicaeae family such as broccoli, cauliflower, cabbage, Brussel sprouts, turnip and rapeseed "as these have the potential to trigger an adverse reaction" [8]. In addition, in its Scientific Opinion on the safety of "rapeseed protein isolate" as a novel food ingredient, the European Food Safety Authority reassured on the toxicological aspects, but stated, "...the risk of sensitization to rapeseed cannot be excluded and it is likely that rapeseed can trigger allergic reactions in mustard allergic subjects" [9].

If it comes true, the doctors should be aware of this risk, and the population protected from it. Following the logic of this advice, when an industry is commercializing prepackaged foods containing rapeseed, they must also label them as potentially cross-reactive with mustard. Is this sound, or would it expose allergic individuals to unnecessary restrictions due to PFAL type II [10]?

Thus, the problem is of interest not only of doctors and patients, but also of food industry, drug manufacturers and the regulatory authorities. In this review, we aim to provide the elements for a risk assessment of rapeseed allergy in the general population. We will review the literature to assess, for each molecular allergen, the risk of cross-reactions among rapeseed and mustard.

\section{Rapeseed}

Rapeseed (Brassica napus), also known as rape, oilseed rape, rapa, rappi, and canola [11], is a bright-yellow flowering. The plant is cultivated mainly for its oil-rich seed, the third-largest source of vegetable oil in the world [12]. Rapeseed oil is one of the oldest vegetable oils, but has been used in limited quantities due to high levels of erucic acid, which is damaging to cardiac muscle of animals, and glucosinolates, which made it less nutritious in animal feed. In 1981, a deadly outbreak of disease in Spain, known as toxic oil syndrome, was caused by the consumption of rape oil for industrial use that was fraudulently sold as olive oil to be consumed in cooking, salads, and other foods. Symptoms appeared as a typical pneumonia with interstitial infiltrates on chest X-ray, complicated by pulmonary hypertension in a significant number of cases [13]. Thus, rapeseed oil is subjected to regulatory limitations: the United States Food and Drug Administration recognized rapeseed canola-equivalent oil, also known as 'low erucic acid rapeseed (LEAR) oil', as safe. Canola oil is limited to a maximum of $2 \%$ erucic acid by weight in the USA [14] and $5 \%$ in the EU [15]. In 2015-6, the market for rapeseed has gone up considerably and cash market prices exceeded the previous year's level for several weeks. The upward trend continues since some years [16], for at least two reasons. First, the Food and Agriculture Organization of the United Nations (FAO) encourages the use of novel protein sources (including specifically rapeseed) to reduce the energetic costs of the food production [17]. Second, evidence is emerging that Brassicaceae may exert an asthma-preventing action. For instance, the consumption of kimchi - a traditional fermented Korean side dish made from napa cabbage and radish - is inversely associated with the incidence of asthma [18]. Broccoli have been shown to activate NK cells during asthmainducing respiratory infections [19]. Their consumption is being proposed as a nutritional antioxidant intervention for reducing influenza risk among populations at risk of asthma [20]. Cataplasms of white mustard seed, traditionally used in China to prevent asthma, are currently studied for their mechanisms of action [21]. Thus, we may expect an increase of the use of Brassicaceae as foods or dietary supplements. This could increase the odds of allergic reactions [22].

\section{Rapeseed allergens}

Rapeseed pollen contains known allergens (Table 1), but rape pollen do not causes hay fever, as rape is an insect-pollinated (entomophilous) crop, whereas hay fever is usually caused by wind-pollinated plants. The inhalation of rape dust may cause asthma in agricultural workers. As rapeseed is consumed as an oil, containing only little amounts of protein allergens, rapeseed food allergy is practically an unknown [23]. Hereafter, we will indicate the single rapeseed potential food allergens.

Table 1 rapeseed allergens and their IUS code

\begin{tabular}{lll}
\hline Allergen & Name & Code \\
\hline Bra n & Napin & 1750 \\
Bra n 1 & Napin & 169 \\
Bra n 1.0101 & Napin & 3162 \\
Bra n 4 & Polcalcin & 710 \\
Bra n 7 & Polcalcin & 170 \\
Bra n 8 & Profilin & 1073 \\
Bra n PG & Polygalactonurase & 1072 \\
& Cruciferin & $\mathrm{nf}$ \\
\hline
\end{tabular}




\section{Bra $\mathbf{n} 1$ (Napin n III)}

Napins have been identified as rapeseed storage proteins in the '90s, but have been characterized as allergens only recently. Proteomic methods indicate that these protein allergens accumulate during seed development [24]. Napins represent approximately $20 \%$ of the total protein in rapeseed flour. They consist of a small and large chain linked by disulphide bonds [25], resistant to pepsin digestion and denaturation caused by heat and low $\mathrm{pH}$ [26]. Thus, it is possible that napin is not destroyed during conventional food processing.

Napins are ligands of sIgE, as shown by IgE immunoblotting and IgE ELISA in the sera from 72 atopic children with positive SPT responses to oilseed and turnip rape. They are a group of homologous proteins belonging to the family of $2 \mathrm{~S}$ albumins, MW 9.5- to $14.5-\mathrm{kd}$. About $80 \%$ of the patients had IgE to purified napins from both plants at ELISA. In SPTs purified napins caused positive reactions in all children tested [27]. These allergens seem more frequently positive in Finnish children with atopic dermatitis (AD) than in French AD children. IgE antibodies to purified $2 \mathrm{~S}$ albumin allergens showed cross-wise IgE inhibition patterns among turnip rape, oilseed rape and mustard seeds. Thus, the $2 \mathrm{~S}$ albumin allergens in the seeds of these plants are highly cross-reactive and could be important sensitizers in children with atopic dermatitis [28].

\section{Bra n 4 - calcium - binding protein, polcalcin}

Polcalcins are a family of pollen allergens identified in several evolutionarily distant dicotyledon and monocotyledon plants. They belong to the family of calciumbinding proteins, characterized by a variable number of motifs, termed EF-hands, which consist of two perpendicularly placed alpha-helics and an inter-helical loop forming a single calcium-binding site. Due to their ability to bind and transport calcium as well as to interact with a variety of ligands in a calcium-dependent manner, they fulfill important biological functions in eukaryotic cells. Polcalcinis specifically are EF-hand proteins believed to assist in regulating pollen-tube growth (see infra). After parvalbumin, a three EF-hand fish allergen, calcium-binding allergens were discovered in pollens of trees, grasses and weeds and, recently, also as autoallergens in man. Although only a small percentage of atopic individuals displays IgE reactivity to calcium-binding allergens, these allergens may be important because of their ability to cross-sensitize allergic individuals. Confrontation and stability, as well as IgE recognition of calcium-binding allergens, greatly depend on the presence of protein-bound calcium ions. It is thus likely that hypoallergenic derivatives of calcium-binding allergens can be engineered by recombinant DNA technology for immunotherapy of sensitized patients [29].
Polcalcins were identified in 1995 as allergens in the anthers of Brassica rapa L. and B. napus L. using the serum IgE from a patient specifically allergic to Brassica pollen. At that time, botanicals were able to identify genotypic and phenotypic sequences of a group I polcalcin of 79 amino acids, and a group II polcalcin of 83 amino acids, with microheterogeneity [30]. Later on, Bra - 4, a polcalcin, has been identified as an inhalant allergen from the pollen of Brassica. This is a $8.6-\mathrm{kD}$ protein with two EF-hand calcium-binding motifs, member of a small gene family in Brassica napus. Homologs have been detected in Arabidopsis, from which one gene has been cloned, and in snapdragon (Antirrhinum majus). Expression of the gene in B. napus was limited to male tissues and occurred during the pollen-maturation phase of anther development. Both the B. napus and Arabidopsis proteins interact with calcium, and the potential for a calcium-dependent conformational change was demonstrated. Given this affinity for calcium, the cloned genes were termed BPC1 and APC1 (B. napus and Arabidopsis pollen calcium-binding protein 1 , respectively). Immunolocalization studies demonstrated that BPC1 is found in the cytosol of mature pollen. However, upon pollen hydration and germination, there is some apparent leakage of the protein to the pollen wall. BPC1 is also concentrated on or near the surface of the elongating pollen tube. The essential nature of calcium in pollen physiology, combined with the properties of BPC1 and its high evolutionary conservation, suggests that this protein plays an important role in pollination by functioning as a calcium-sensitive signal molecule [31].

\section{Bra $\mathbf{n} 7$ - calcium - binding protein, polcalcin}

Another polcalcin has been identified as allergen in rapeseed by immunoblot, immunoblot inhibition and specific monoclonal antibodies using sera from 89 patients sensitized to rapeseed. Two low-molecular-weight allergens of $6 / 8 \mathrm{kD}$ were identified in $50 \%$ of patients, totally cross-reactive with rye pollen and moderately with birch pollen. Binding to the $6 / 8-\mathrm{kD}$ rape allergen could be effectively inhibited by rAln $\mathrm{g} 2$, a calciumbinding protein from alnus. These data demonstrated that this little calcium-binding protein, thinner than Bran 4, is an important respiratory allergen of rapeseed [32]. It exhibits wide cross-reactivity with tree pollens, thimothy grass, and herbs [33].

\section{Bra $\mathbf{n} 8$ - actin-binding protein, profilin}

Allergenic plant profilins constitute a highly conserved family with sequence identities of 70 to $85 \%$ among each other but low identities of 30 to $40 \%$ with nonallergenic profilins from other eukaryotes, including human beings. Profilins are present as food allergens in a variety of fruits and vegetables, and have been associated 
with non-anaphylactic reactions. In rapeseed, they were found at immunoblot, immunoblot inhibition and/or specific monoclonal antibodies in $34 \%$ of sensitized patients [12]. An anti-profilin-specific monoclonal antibody bound specifically to this $14-\mathrm{kD}$ protein. Later on, the $14-\mathrm{kD}$ protein, purified from the other allergens, was precisely identified by PLP affinity chromatography as a single protein of $14.5 \mathrm{kD}$ and further identified as a profilin by three polyclonal rabbit antisera. It is very similar to ragweed and tobacco pollen profilin and the Cterminus of birch profilin. Skin prick tests were positive with Bra $\mathrm{n} 8$ in two thirds of patients [34].

\section{Bra n PG - polygalactonurase}

The third group of proteins identified as allergenic in oilseed rape is a large group of 27 to $69-\mathrm{kD}$ allergens, rich in carbohydrate determinants [12]. This cluster is cross-reactive with grass pollen group 4 allergens. They peak at a molecular mass around $43 \mathrm{kD}$. From this zone, two isoforms of the polygalacturonase enzyme were identified by microsequencing, confirmed by MALDITOF mass spectrometry analysis. As $80 \%$ of rapeseed sensitive patients show reactivity to this cluster, Bra $\mathrm{n}$ PG seems to be the main allergen for some patients [35].

\section{Cruciferin}

The main seed storage protein in these plants is an $11 \mathrm{~S}$ globulin, cruciferin, a large, neutral, oligomeric protein synthesized in rapeseed during the seed development. It is composed of six subunit pairs. Each pair consists of one heavy $\alpha$ chain $(30 \mathrm{kDa})$ and one light $\beta$ chain $(20 \mathrm{kDa})$. Four different subunit pairs exist. Investigations using two-dimensional electrophoresis showed that the majority of $\alpha$ and $\beta$ chains of each subunit are disulfide-linked [36]. Cruciferin is one of the major allergens also in white mustard [37] and hazelnut [38].

\section{Prevalence of allergy to rapeseed}

IgE-mediated food allergy to members of the Brassicaceae family is uncommon [39-41], except for mustard [42-44]. Rapeseed allergy been described among rapeseed workers by contact and/or inhalation of rapeseed proteins [45], but rapeseed food allergy is very rare, so that no specific epidemiologic study has been dedicated to it. Despite its wide consumption in China and Africa, no single case of allergic reaction to rapeseed flour or oil can be found in the literature in that countries. However, its ability to determine clinical reactions has been demonstrated in experimental models (see infra).

Regarding rapeseed sensitization, children with IgEmediated allergy to vegetable foods may react to seeds of oilseed rape and turnip rape in skin prick tests (SPTs), but no studies have formally addressed the specific question in open populations. A Finnish study among children with atopic dermatitis suspected for food allergy showed that $11 \%(206 / 1887)$ of such children were SPT-positive to oilseed (Brassica napus) and/or turnip (Brassica rapa) rape [46]. None of them had immediate or delayed symptoms from this sensitization. A further study examined 64 children with atopic dermatitis and a positive skin prick test to turnip rape and/or oilseed rape. These were found polysensitized, with positive skin prick tests reactions and IgE antibodies to various foods (cow's milk, egg, wheat, mustard) and pollens (birch, timothy, mugwort). They had often associated asthma (36\%) and allergic rhinitis (44\%). Children with atopic dermatitis sensitized to oilseed rape and turnip rape had high frequency of associated sensitizations to all foods and pollens tested, showing that oilseed plant sensitization affects especially atopic children who have been sensitized to multiple allergens. In other words, this seems a sensitization without clinical correlates.

To characterize the clinical significance of these sensitizations, i.e. the ability of rapeseed flour to determine allergic reactions, 28 children with clearly positive SPT ( $>$ or $=5 \mathrm{~mm}$ ) were subjected to labial challenge with turnip rape seeds followed, if negative, by open oral challenge for up to 7 days. Twenty-five ( $89 \%)$ of the 28 showed a positive challenge reaction to turnip rape. Seventeen reacted with labial whealing, and eight in oral challenge with facial urticaria, flare-up of AD or abdominal symptoms. This indicates that turnip rape and oilseed rape may act as allergy triggers in young children with $\mathrm{AD}$ [47]. Later on, food challenges with turnip rape and mustard were performed to 14 Finnish and 14 French children with atopic dermatitis and positive skin prick test to turnip rape. Open labial or oral challenge to turnip rape was positive in 14 (100\%) Finnish and five (36\%) French children and mustard challenge in five Finnish and five French children [8]. These findings indicate that turnip rape flour may act as an allergen and may cross-react with mustard, but the scarcity of the exposed data makes impossible to estimate the frequency of sensitization in different geographical areas. This is even truer outside Europe, where epidemiological studies on food allergy are practically absent. That said, the majority of rapeseed is consumed as oil, available as cold-pressed or refined oil. Refined oils do not cause allergic reactions, as they do not contain proteins. During the manufacture of cold-pressed oils, however, oil is pressed from the oilseeds without heating and the sediment from the seeds is settled down. Thus these kinds of oils may contain traces of seed proteins. Allergenic napins (2S albumin) and allergenic cruciferins (11S globulin) can be detected in cold-pressed rapeseed oils with sensitive proteomic methods [48]. However, the clinical importance of the exposure to low concentration such allergens in rapeseed oil is not known. 


\section{Potentially dangerous thresholds of contamination}

As probably no clinical reaction to rapeseed has even been described, it is impossible to express thresholds for a risk of allergic reactions. Reviewing the data on threshold levels for food allergic reactions, a strong interindividual variability appears immediately. The calculated dose of fatal anaphylaxis to peanut (one of the most frequent event) varies from few milligrams to several tens of grams [49]. The interindividual threshold levels differ substantially and it is difficult to reach general recommendations for allergic subjects [50]. To overcome these limits, recent studies afforded the topic at a Europeanwide level, with the aim to describe the spectrum of provoking doses for food allergy and ultimately to assist the European Community in their legislation [51]. No specific evaluation of rapeseed allergy has been included.

\section{Cross-reactivity among rapeseed and mustard seed}

Anaphylactic reactions set off by the ingestion of a small amount of mustard sauce are described since longtime [52]. Several different mustard species are commonly used in food: white mustard (Sinapis alba), black mustard (Brassica nigra) and brown mustard (Brassica juncea) are the most common [53]. White mustard is detected in the "green" and black/brown mustard in the "yellow" channel. In a prospective study on mustard allergic patients, 38 patients (10.5 \% reporting systemic anaphylaxis) showed association with mugwort pollen sensitization (97.4 \%) and other members of Brassicaceae family. Associations with nut (97.4\%), leguminosae (94.7 \%), corn (78.9 \%), and Rosaceae (89.5 \%) sensitizations were also reported. Around $40 \%$ of these food sensitizations were symptomatic, including food-dependent exercise-induced anaphylaxis in six patients. These data prompted the definition of 'mustard-mugwort allergy syndrome' [54], and allergens in mustard seed have been extensively studied (Table 2 and Table 3 ).

Bra ni and Bra $\mathbf{r}$ do not have a specific literature. Bra $\mathbf{j}$ is a specific allergen of the Oriental mustard, a food available also in transgenic form (Brassica juncea expressing choline oxidase gene from Arthrobacter globiformis that provides resistance against abiotic stresses) [55]. The major allergenic protein in yellow mustard (Sinapis alba) is the $2 \mathrm{~S}$ napin Sin a 1. It shows no cross reactivity with other proteins of mustard or other Brassicaceae proteins of similar genetic homology [56]. Sin a 2, a $11 \mathrm{~S}$ globulin, has been characterized as a major $51 \mathrm{kDa}$ allergen. The allergen was dissociated in 2 chains of 36 and $23 \mathrm{kDa}$, which also bound IgE. The common basis is a seed storage 11S globulin belonging to the Cupin super family. It has been associated with severe allergic reactions and is involved in cross-reactivity at

Table 2 Mustard seed allergens, their origin and their IUS code

\begin{tabular}{|c|c|c|}
\hline Allergen & Source & Code \\
\hline Bra ni & Black Mustard, Brassica nigra & 1682 \\
\hline Bra j & Brassica juncea, Oriental Mustard & 1749 \\
\hline Bra $r$ & Bird Rape, Brassica rapa, Field Mustard, Turnip, Turnip Mustard & 2022 \\
\hline $\operatorname{Sin} a$ & Bird Rape, Brassica alba, Sinapis alba, Turnip, White Mustard & 1972 \\
\hline Bra j 1 & Brassica juncea, Oriental Mustard & 168 \\
\hline Bra r 1 & Bird Rape, Brassica rapa, Field Mustard, Turnip, Turnip Mustard & 2682 \\
\hline Bra 3 & Bird Rape, Brassica rapa, Field Mustard, Turnip, Turnip Mustard & 1060 \\
\hline Sin a 1 & Bird Rape, Brassica alba, Sinapis alba, Turnip, White Mustard & 627 \\
\hline Sin a 1.0101 & Bird Rape, Brassica alba, Sinapis alba, Turnip, White Mustard & 3477 \\
\hline Sin a 1.0104 & Bird Rape, Brassica alba, Sinapis alba, Turnip, White Mustard & 1662 \\
\hline Sin a 1.0105 & Bird Rape, Brassica alba, Sinapis alba, Turnip, White Mustard & 1663 \\
\hline Sin a 1.0106 & Bird Rape, Brassica alba, Sinapis alba, Turnip, White Mustard & 1664 \\
\hline Sin a 1.0107 & Bird Rape, Brassica alba, Sinapis alba, Turnip, White Mustard & 1665 \\
\hline Sin a 1.0108 & Bird Rape, Brassica alba, Sinapis alba, Turnip, White Mustard & 1666 \\
\hline Sin a 2 & Bird Rape, Brassica alba, Sinapis alba, Turnip, White Mustard & 2693 \\
\hline Sin a 2.0101 & Bird Rape, Brassica alba, Sinapis alba, Turnip, White Mustard & 4034 \\
\hline Sin a 3 & Bird Rape, Brassica alba, Sinapis alba, Turnip, White Mustard & 7634 \\
\hline Sin a 3.0101 & Bird Rape, Brassica alba, Sinapis alba, Turnip, White Mustard & 7635 \\
\hline Sin a 4 & Bird Rape, Brassica alba, Sinapis alba, Turnip, White Mustard & 7636 \\
\hline Sin a 4.0101 & Bird Rape, Brassica alba, Sinapis alba, Turnip, White Mustard & 7637 \\
\hline
\end{tabular}


Table 3 If a company will label rapeseed as possible cross-reactor with mustard, they should also label [63-70]

\begin{tabular}{|c|c|c|}
\hline ...Celery & as possibly cross-reactive with.... & ... anise, fennel, coriander, cumin, caraway, carrot, dill, lovage, parsley... \\
\hline ...Cereals containing gluten & & ... triticale, rye, barley, oat, rice, maize \\
\hline$\ldots$ Egg & & ... poultry \\
\hline ...Peanut & & ... beans, lentils, lupin, chick pea.... \\
\hline ....Nuts & & ... peach, apricot, kiwifruit... \\
\hline .... Soy & & ... peas, lentils, kidney, lima and navy beans... \\
\hline ...Milk & & ... beef \\
\hline ...Mustard & & ... rapeseed, sunflower seed, ricinus .... \\
\hline
\end{tabular}

the IgE level with tree nuts and peanut. Brassicaceae do have cruciferin and Lipid-Transfer Protein (LTP), able to act as allergens and even to determine severe reactions (as Bra o 3 in patients allergic to Cabbage [57]).

The mustard LTP is Sin a 3, whose specific cDNAs has been identified and encodes for a mature proteins of 92 amino acids. Sin a 3 shows $54 \%$ identity with allergenic LTP from peach. Sin a 4 specific DNA has been also sequenced, encoding for a protein of 131 amino acids that belong to profilin family. Sin a 4 showed $80 \%$ in - vitro identity with allergenic profilin from melon [58].

In vitro studies showed cross-reactivities among mustard and other vegetables, such as nuts, peach, and melon, and other Brassicaceae. From the analysis of the examined studies, one can conclude than - although cross-sensitization cannot be excluded - no crossreactivity has been demonstrated among mustard and rapeseed in vivo at inhalant and food allergy level.

\section{Conclusions}

In a time when new allergenic foods are described every year, there is concern in the public opinion about the possibility of hidden allergens in processed foods [59]. The consumers are also exposed to uncontrolled lay information on the possible risks of 'new' food allergies. Recent examples show how this can translate in the creation of social alarm, for disparate reasons [60]. The implementation of PFAL type II could add to their panic, but would be necessary if cross-reactivity are frequent as in the case of milk.

In our case, a cross - reaction among rapeseed and mustard is theoretically possible but it has never been documented. In this situation, is it opportune to label a food as potentially cross-reactive on the ground of a theoretical possibility only? We fear that this would add confusion among the consumers and health professionals who provide them with advice on how to manage their condition $[61,62]$. Allergists spend the majority of their clinical work to prevent unnecessary elimination of foods, and PFAL type II would contradict their efforts.
If the contrary would apply, in the context of the prepacked snacks production at least the alerts indicated in Table 2 should be activated [63-70]: we have no doubt that this would worsen the quality of life of allergy sufferers.

\section{Acknowledgements}

Not applicable.

\section{Funding}

NO sources of funding for the review reported to be declared.

\section{Authors' contributions}

AF conceived of the study, and participated in its design and coordination and helped to draft the manuscript. LD helped to draft the manuscript CR helped to draft the manuscript OM helped to draft the manuscript VF helped to draft the manuscript. All authors read and approved the final manuscript.

\section{Competing interests}

The authors declare that they have no competing interests.

\section{Consent for publication}

This manuscript does not contain any individual persons data. Not applicable.

Ethics approval and consent to participate

Not applicable.

Received: 27 August 2016 Accepted: 18 October 2016

Published online: 01 November 2016

\section{References}

1. EU Commission Directive 2007/68/EC. http://eur-lex.europa.eu/legalcontent/EN/TXT/?qid=1471433613170\&uri=CELEX:32007L0068. Accessed $17^{\text {th }}$ August 2016.

2. U.S. Food Allergen Labeling and Consumer Protection Act (Public Law 108-282 2004, Title II). http://www.fda.gov/Food/GuidanceRegulation/ GuidanceDocumentsRegulatoryInformation/Allergens/ucm106187.htm. Accessed $17^{\text {th }}$ August 2016.

3. Canadian Food and Drug Regulations - Enhanced Labelling for Food Allergen and Gluten Sources and Added Sulphites. http://gazette.gc.ca/rp-pr/p2/2011/ 2011-02-16/html/sor-dors28-eng.html. Accessed 17 $7^{\text {th }}$ August 2016.

4. DunnGalvin A, Chan CH, Crevel R, Grimshaw K, Poms R, Schnadt S, Taylor $\mathrm{SL}$, et al. Precautionary allergen labelling: perspectives from key stakeholder groups. Allergy. 2015;70:1039-51.

5. Allen KJ, Turner PJ, Pawankar R, Taylor S, Sicherer S, Lack G, Rosario N, Ebisawa M, Wong G, Mills EN, Beyer K, Fiocchi A, Sampson HA. Precautionary labelling of foods for allergen content: are we ready for a global framework? World Allergy Organ J. 2014;7:10.

6. http://www.hc-sc.gc.ca/fn-an/alt formats/pdf/label-etiquet/allergen/ precaution_label-etiquette-eng.pdf. Accessed 17 $7^{\text {th }}$ August 2016. 
7. Fiocchi A, Restani P, Leo G, Martelli A, Bouygue GR, Terracciano L, Ballabio C, Valsasina R. Clinical tolerance to lactose in children with cow's milk allergy. Pediatrics. 2003;112:359-62.

8. http://www.hc-sc.gc.ca/fn-an/pubs/label-etiquet/mustard-moutarde/indexeng.php. Accessed 24 Oct 2016.

9. EFSA NDA Panel (EFSA Panel on Dietetic Products, Nutrition and Allergies) 2013. Scientific Opinion on the safety of "rapeseed protein isolate" as a Novel Food ingredient. EFSA J. 2013;1:3420.

10. Allen KJ, Remington BC, Baumert $\lrcorner$, Crevel RW, Houben GF, Brooke-Taylor $\mathrm{S}$, et al. Allergen reference doses for precautionary labeling (VITAL 2.0): clinical implications. J Allergy Clin Immunol. 2014;133:156-64.

11. NPGS/GRIN. Taxonomy for Plants. National Germplasm Resources Laboratory. Beltsville: USDA, ARS, National Genetic Resources Program; 2015.

12. Oilseeds: World Markets and Trade/USDA FAS (PDF). Fas.usda.gov. Accessed 22 October 2015.

13. Posada de la Paz M, Philen RM, Borda Al. Toxic oil syndrome: the perspective after 20 years. Epidemiol Rev. 2001;23:231-47.

14. Code of Federal Regulations Title 21. Volume 3, 21CFR184.1555.

15. Commission Directive 80/891/EEC of 25 July 1980 relating to the Community method of analysis for determining the erucic acid content in oils and fats intended to be used as such for human consumption and foodstuffs containing added oils or fats. EurLex Off J. 254.

16. Union for the Promotion of Oil and Protein Plants (Union zur Förderung von Oel- und Proteinpflanzen e. V.), chart of development of rapeseed prices, http://www.ufop.de/files/9714/6487/1369/GdW_EN_2216_2048.jpg. Accessed $16^{\text {th }}$ August 2016

17. Boland MJ, Rae AN, Vereijken JM, Meuwissen MPM, Fischer ARH, Van Boekel MAJS, Rutherfurd SM, Gruppen H, Moughan PJ, Hendriks WH. The future supply of animal-derived protein for human consumption. Trends Food Sci Technol. 2013;29:62-73.

18. Kim H, Oh SY, Kang MH, Kim KN, Kim Y, Chang N. Association between kimchi intake and asthma in Korean adults: the fourth and fifth Korea National Health and Nutrition Examination Survey (2007-2011). J Med Food. 2014;17:172-8.

19. Müller L, Meyer M, Bauer RN, Zhou H, Zhang H, Jones S, Robinette C, Noah $T L$, Jaspers I. Effect of broccoli sprouts and live attenuated influenza virus on peripheral blood Natural Killer cells: a randomized, double-blind study. PLoS One. 2016;11:e0147742

20. Noah TL, Zhang H, Zhou H, Glista-Baker E, Müller L, Bauer RN, Meyer M, Murphy PC, Jones S, Letang B, Robinette C, Jaspers I. Effect of broccoli sprouts on nasal response to live attenuated influenza virus in smokers: a randomized, double-blind study. PLoS One. 2014;9:e98671.

21. Du LN, Zhu WN, Liu XY, Chen WY, Yu X, Li M, Jin YG. Preparation, in vitro and in vivo evaluation of cataplasm of white mustard seed varnish to prevent asthma. Zhongguo Zhong Yao Za Zhi. 2014;39:4596-602.

22. van der Spiegel M, Noordam MY, van der Fels-Klerx HJ. Safety of nove protein sources (insects, microalgae, seaweed, duckweed, and rapeseed) and legislative aspects for their application in food and feed production. Compr Rev Food Sci Food Saf. 2013;12:662-78

23. Gylling H. Rapeseed oil does not cause allergic reactions. J Allergy. 2006;61:895

24. Thelen JJ. Proteomics tools and resources for investigating protein allergens in oilseeds. Regul Toxicol Pharmacol. 2009;54:S41-5.

25. Lonnerda B, Janson JC. Studies on Brassica seed proteins. 1. Low molecularweight proteins in rapeseed isolation and characterization. Biochimica Et Biophysica Acta. 1972;278:175-83.

26. Murtagh GJ, Archer DB, Dumoulin M, Ridout S, Matthews S, Arshad SH. In vitro stability and immunoreactivity of the native and recombinant plant food 2S albumins Ber e 1 and SFA-8. Clin Exp Allergy. 2003;33:1147-52.

27. Puumalainen TJ, Poikonen S, Kotovuori A, Vaali K, Kalkkinen N, Reunala T, Turjanmaa K, Palosuo T. Napins, 25 albumins, are major allergens in oilseed rape and turnip rape. J Allergy Clin Immunol. 2006;117:426-32.

28. Poikonen S, Rance F, Puumalainen T, Le Manach G, Reunala T, Turjanmaa K. Sensitization and allergy to turnip rape: a comparison between the Finnish and French children with atopic dermatitis. Acta Paediatr. 2008;98:310-5.

29. Valenta R, Hayek B, Seiberler S, Bugajska-Schretter A, Niederberger V, Twardosz A, Natter S, Vangelista L, Pastore A, Spitzauer S, Kraft D. Calcium-binding allergens: from plants to man. Int Arch Allergy Immunol. 1998;117:160-6.

30. Toriyama K, Okada T, Watanabe M, Ide T, Ashida $T$, Xu H, Singh MBA cDNA clone encoding an IgE-binding protein from Brassica anther has significant sequence similarity to $\mathrm{Ca}(2+)$-binding proteins. Plant $\mathrm{Mol}$ Biol. 1995;29:1157-65.
31. Rozwadowski K, Zhao R, Jackman L, Huebert T, Burkhart WE, Hemmingsen SM, Greenwood J, Rothstein SJ. Characterization and immunolocalization of a cytosolic calcium-binding protein from Brassica napus and Arabidopsis pollen. Plant Physiol. 1999;120:787-8.

32. Focke $M$, Hemmer W, Hayek $B$, Gotz M, Jarisch R. Identification of allergens in oilseed rape (Brassica napus) pollen. Int Arch Allergy Immunol. 1998;117:105-12.

33. Wopfner N, Dissertori O, Ferreira F, Lackner P. Calcium-binding proteins and their role in allergic diseases. Immunol Allergy Clin North Am. 2007;27:29-44.

34. Focke M, Hemmer W, Valenta R, Gotz M, Jarisch R. Identification of oilseed rape (Brassica napus) pollen profilin as a cross-reactive allergen. Int Arch Allergy Immunol. 2003;132:116-23.

35. Chardin H, Mayer C, Senechal H, Poncet P, Clement G, Wal JM, Desvaux FX, Peltre G. Polygalacturonase (pectinase), a new oilseed rape allergen. Allergy. 2003:58:407-11.

36. Sjodahl S, Rodin J, Rask L. Characterization of the $12 \mathrm{~S}$ globulin complex of Brassica napus. Evolutionary relationship to other 11-12S storage globulins. Eur J Biochem. 1991;196:617-21.

37. Palomares O, Cuesta-Herranz J, Vereda A, Sirvent S, Villalba M, Rodriguez R. Isolation and identification of an $11 \mathrm{~S}$ globulin as a new major allergen in mustard seeds. Ann Allergy Asthma Immunol. 2005;94:586-92.

38. Beyer K, Grishina G, Bardina L, Grishin A, Sampson HA. Identification of an $11 \mathrm{~S}$ globulin as a major hazelnut food allergen in hazelnut-induced systemic reactions. J Allergy Clin Immunol. 2002;110:517-23.

39. Sayed F, Manzur F, Marguery MC, Bayle P, Bazex J. Urticarial manifestations due to Raphanus niger. Contact Dermatitis. 1995;32:241.

40. Lee $\mathrm{YH}$, Lee $\mathrm{JH}$, Kang HR, Ha JH, Lee BH, Kim SH. A case of anaphylaxis induced by contact with young radish (Raphanus sativus L). Allergy, Asthma Immunol Res. 2015;7:95-7.

41. Sousa N, Gaspar A, Morais-Almeida M. Anaphylaxis to Raphanus niger. Allergy. 2010;65:1202.

42. Panconesi E, Sertoli A, Fabbri P, Giorgini S, Spallanzini P. Anaphylactic shock from mustard after ingestion of pizza. Contact Dermatitis. 1980;6:294-5.

43. Rancé F, Kanny G, Dutau G, Moneret-Vautrin DA. Food hypersensitivity in children: clinical aspects and distribution of allergens. Pediatr Allergy Immunol. 1999;10:33-8.

44. Rancé F. Mustard allergy as a new food allergy. Allergy. 2003;58:287-8.

45. Compes E, Palomares O, Fernandez-Nieto M, Escudero C, Cuesta-Herranz J. Allergy to turnip seeds in a bird fancier. Allergy. 2007:62:1472-3.

46. Poikonen S, Puumalainen TJ, Kautiainen H, Palosuo T, Reunala T, Turjanmaa K. Sensitization to turnip rape and oilseed rape in children with atopic dermatitis: a case-control study. Pediatr Allergy Immunol. 2008;19:408-11.

47. Poikonen S, Puumalainen TJ, Kautiainen H, Burri P, Palosuo T, Reunala T, Turjanmaa K. Turnip rape and oilseed rape are new potential food allergens in children with atopic dermatitis. Allergy. 2006;61:124-7.

48. Puumalainen TJ, Puustinen A, Poikonen S, Turjanmaa K, Palosuo T, Vaali K. Proteomic identification of allergenic seed proteins, napin and cruciferin, from cold-pressed rapeseed oils. Food Chem. 2015:175:381-5.

49. Mullins RJ. Anaphylaxis: risk factors for recurrence. Clin Exp Allergy. 2003;33:285-90

50. Brockow K, Ring J. Food anaphylaxis. Anal Bioanal Chem. 2009:395:17-23.

51. Ballmer-Weber BK, Fernandez-Rivas M, Beyer K, Defernez M, Sperrin M, Mackie AR, Salt LJ, Hourihane JO, Asero R, Belohlavkova S, Kowalski M, de Blay F, Papadopoulos NG, Clausen M, Knulst AC, Roberts G, Popov T, Sprikkelman AB, Dubakiene R, Vieths S, van Ree R, Crevel R, Mills EN. How much is too much? Threshold dose distributions for 5 food allergens. J Allergy Clin Immunol. 2015:135:964-71.

52. Monreal P, Botey J, Pena M, Marin A, Eseverri JL. Mustard allergy. Two anaphylactic reactions to ingestion of mustard sauce. Ann Allergy. 1992;69:317-20.

53. Palle-Reisch M, Cichna-Markl M, Hochegger R. Development and validation of a duplex real-time PCR assay for the simultaneous detection of three mustard species (Sinapis alba, Brassica nigra and Brassica juncea) in food. J Food Chem. 2014;153:66-73.

54. Figueroa J, Blanco C, Dumpierrez AG, Almeida L, Ortega N, Castillo R, Navarro L, Perez E, Gallego MD, Carrillo T. Mustard allergy confirmed by double-blind placebo-controlled food challenges: clinical features and cross-reactivity with mugwort pollen and plant-derived foods. Allergy. 2005;60:48-55.

55. Singh AK, Mehta AK, Sridhara S, Gaur SN, Singh BP, Sarma PU, Arora N. Allergenicity assessment of transgenic mustard (Brassica juncea) expressing bacterial codA gene. Allergy. 2006;61:491-7.

56. Marambe HK, Mclntosh TC, Cheng B, Wanasundara JPD. Quantification of major 25 allergen protein of yellow mustard using anti-Sin a 1 epitope antibody. Food Control. 2014;44:233-41. 
57. Palacin A, Cumplido J, Figueroa J, Ahrazem O, Sanchez-Monge R, Carrillo T, Salcedo G, Blanco C. Cabbage lipid transfer protein Bra o 3 is a major allergen responsible for cross-reactivity between plant foods and pollens. J Allergy Clin Immunol. 2006:117:1423-9.

58. Sivent S, Palomares O, Vereda A, Villalba M, Cuesta-Herranz J, Rodriguez R. nsLTP and profilin are allergens in mustard seeds: cloning, sequencing and recombinant production of Sin a 3 and Sin a 4. Clin Exp Allergy. 2009;39:1929-36.

59. Schnadt S. Hidden allergens in processed food. The consumer perspective. Bundesgesundheitsblatt Gesundheitsforschung Gesundheitsschutz. 2012;55: 385-93.

60. Waggoner MR. Parsing the peanut panic: the social life of a contested food allergy epidemic. Soc Sci Med. 2013;90:49-55.

61. Ju SY, Park JH, Kwak TK, Kim KE. Attitudes and preferences of consumers toward food allergy labeling practices by diagnosis of food allergies. Nutr Res Pract. 2015;9:517-22.

62. Hefle SL, Furlong TJ, Niemann L, Lemon-Mule H, Sicherer S, Taylor SL. Consumer attitudes and risks associated with packaged foods having advisory labeling regarding the presence of peanuts. J Allergy Clin Immunol. 2007;120:171-6.

63. Moneret-Vautrin DA, Morisset M, Lemerdy P, Croizier A, Kanny G. Food allergy and IgE sensitization caused by spices: CICBAA data (based on 589 cases of food allergy). Allerg Immunol (Paris). 2002;34:135-40.

64. Block G, Tse KS, Kijek K, Chan H, Chan-Yeung M. Baker's asthma. Studies of the cross-antigenicity between different cereal grains. Clin Allergy. 1984;14:177-85.

65. Gomez Torrijos E, García Rodriguez C, Rodriguez J, De la Roca F, Cárdenas R, Alfaya F, Pineda F, Feo Brito JF. Occupational asthma and eosinophilic esophagitis in a patient with egg-bird syndrome. J Investig Allergol Clin Immunol. 2015;25:61-2.

66. Bernhisel Broadbent J, Sampson HA. Cross-allergenicity in the legume botanical family in children with food hypersensitivity. J Allergy Clin Immunol. 1989;83:435-40.

67. Fiocchi A, Sarratud P, Terracciano L, Vacca E, Bernardini R, Fuggetta D, Ballabio C, Duranti M, Magni C, Restani P. Assessment of the tolerance to lupine-enriched pasta in peanut-allergic children. Clin Exp Allergy. 2009;39:1045-51.

68. Vocks E, Borga A, Szliska C, Seifert HU, Seifert B, Burow G, Borelli S. Common allergenic structures in hazelnut, rye grain, sesame seeds, kiwi, and poppy seeds. Allergy. 1993;48:168-72.

69. Herman E. Soybean allergenicity and suppression of the immunodominant allergen. Crop Sci. 2005;45:462-7.

70. Fiocchi A, Restani P, Bouygue GR, Martelli A. Beef allergy in adults and children. Allergy. 2005;60:126.

\section{Submit your next manuscript to BioMed Central and we will help you at every step:}

- We accept pre-submission inquiries

- Our selector tool helps you to find the most relevant journal

- We provide round the clock customer support

- Convenient online submission

- Thorough peer review

- Inclusion in PubMed and all major indexing services

- Maximum visibility for your research

Submit your manuscript at www.biomedcentral.com/submit

) Biomed Central 